\title{
11
}

\section{Inside a Policymaker's Mind: An Entrepreneurial Approach to Policy Development and Implementation}

\section{Bitange Ndemo}

\section{Introduction}

In 2005, the first day of my new job as permanent secretary (equivalent to a company chief executive officer [CEO]) of Kenya's Ministry of Information and Communications was dramatic. In response to a journalist's question about what I would do about the corruption in the ICT sector, I said, I needed time to study the situation and would do my best to tackle it.

It was the first media interview in my life. I was still trying to understand my new assignment and what it meant to the people of Kenya. The previous night, President Mwai Kibaki had appointed me to work with the Hon. Mutahi Kagwe, who was appointed as minister (equivalent to a nonexecutive chairman of the board). The minister is the political head of the ministry.

B. Ndemo $(\bowtie)$

University of Nairobi, Nairobi, Kenya

(C) The Author(s) 2017

B. Ndemo, T. Weiss (eds.), Digital Kenya,

DOI 10.1057/978-1-137-57878-5_11 
As the top civil servant in the ministry, I was responsible for policymaking and implementation. Everything in the ICT and media sectors ended up on my desk. Corruption issues topped the agenda financially at the ministry. The incumbent telecom, Telkom Kenya, was bleeding financially and losing revenues. Powerful cartels from the private sector in collusion with staff were stealing the company's assets through phony court cases while employees were colluding with international cartels to use the local network without paying (a practice known as the grey market in telecommunications). Publicly owned shares of the new mobile company, Safaricom, had disappeared to a secretive company registered in Guernsey under nominee accounts. Radio frequencies, a public resource, had largely been inappropriately allocated to well-connected individuals and companies, meaning that new entrants could not enter the broadcasting market.

At every function, I faced a barrage of questions from media, donor agencies, and civil society ${ }^{1}$ as well as the public about corruption in the sector. I had no answer to any of these questions, but I kept promising that we would soon deal with all the issues. At that time, the Ministry of Information as well as my post in it had a fairly low profile. I quickly realized that the industry had no policy in place. Previous attempts to have a policy in place were always frustrated by strong vested interests.

The elephant in the room was what we would do to open up the industry by subverting corrupt networks. Before I joined the sector in 2005, privatization was a pressing matter. The new minister and I consulted with the industry and concluded that the answers lay in policy changes. We revised a draft policy document (Government of Kenya 2006) that had been developed earlier and formally adopted it through publication in the Kenya Gazette, the government legal publication. Thereafter, implementation — though characterized by risk — started in earnest.

On paper, Kenya's ICT sector was liberalized. However, the reality was that the incumbent telecom, a creation from the colonial days, controlled key resources such as the international gateway. This monopoly status made calling costs very expensive, sometimes $70 \%$ more than in countries like India. New firms had no option but to endure exorbitant

\footnotetext{
${ }^{1}$ In this case, civil society refers to many different nongovernment organizations and public institutions that represent the interests of Kenya's citizen.
} 
prices, which they passed on to the consumer. The incumbent as the gatekeeper for all international connections controlled the emerging Internet resources. The cartels benefitting in this grey market jealously protected the incumbent's monopoly status and obstructed all efforts at liberalizing the sector. This effectively stifled entrepreneurship and innovation.

\section{Quick Wins from the New Sector Policy: Market Liberalization}

We leveraged the policy document to build sufficient support from the industry in order to open up the sector. We selected five priority areas from the document, including development of and access to affordable infrastructure, content and innovation, capacity building, public-private partnership, and the creation of employment opportunities. In spite of this open approach to policymaking, we faced challenges. The grey market cartels waged war against our initiatives. We received death threats over the opening up of the international telecommunications gateway (ITG) gateways used to link telecommunications operators to the outside world. However, we were determined, and we went ahead and opened up the industry, enabling competitive environment. Because of the death threats, we had to deploy heavy security as we issued new IG licenses. Some members of the media who had been manipulated into accusing us of destroying the national strategic resource, the incumbent Telkom Kenya, eventually began to realize that our actions would be beneficial to all citizens. This was the beginning of the transformation of the sector. However, because of the technological and other changes, we needed a dynamic public policymaking process to accelerate the sector's entrepreneurial reforms.

This chapter is devoted to an examination of the complex policymaking process and entrepreneurial mindset that led to Kenya's breakthrough in ICTs innovation during President Mwai Kibaki's administration. It is mostly narrative in nature, based on recollections of my participation and observations, but it also attempts to use Dror's general systems theory framework (1969) and Edelenbos and Klijn's interactive decision-making theory (2005) to help explain the process. 
It also provides a detailed account of policy development and the institutions that supported Kenya's ICT innovation dynamics, in the process identifying some of the pressing policymaking problems that had to be overcome to facilitate innovative thinking on Kenya's position in the so-called information age. The rest of the chapter is a narration of how innovation policies were made on an ad hoc basis to facilitate development. Three case studies are analyzed using these theories, revealing the two major policy decisions that enabled projects that sparked ICT innovation in Kenya.

\section{The Public Policymaking Process}

Policymaking is a dynamic and complex process and one that is necessary in creating a level playing field in any sector. To reflect changing circumstances - and because they rarely address all pertinent issues exhaustively_policies need regular iterations.

The process of public policymaking is a decision-centric and a goaldriven process (Geurts 2014). Decision-centric processes are those that require decisions to be made. Goal-driven processes are those that require a desired outcome. Goal-driven processes are not static, and iterations are performed until the outcome has been produced. The final outcome is thus often a compromise between the targeted result and the constraints encountered. The framework suggested in this chapter is largely decisioncentric and perhaps explains why Dror (1969) found systems theory to be a more effective tool to explain the continuous and often ad doc nature of policymaking. According to Dror's approach, for policy to be sustained, it requires a continuous input of resources and motivation. It is a dynamic process that changes with time and whose subprocesses and phases vary internally and with respect to each other.

In any country, the policymaking process faces several challenges. In developing countries, discourse on policymaking processes is rare and almost nonexistent, a situation that creates room to manipulate decisions in favour of powerful individuals and engenders corruption.

Dror $(1969,1983)$ recognized that the principal problem with contemporary public policymaking is the constantly widening gap between 
what is known about policymaking and how policy is actually made. Despite ever-complex and evolving challenges, contemporary society relies on static policymaking machinery. At the same time, corporations, private institutions, and government organizations need adaptable guidelines to help them make urgent decisions. For Dror, general system theory referred to the relations between public policymaking and behavioral science and is used to facilitate effective policymaking.

In interactive decision-making theory, according to Edelenbos and Klijn (2005), the public actors, faced with the challenge of translating political objective into policy, attempt alternative ways of creating policy. Perceived problems in policy practices are responsible for protracted decision-making process and the resistance of various actors. Proposed solutions are often not inventive enough for policymakers to make real change. Often, there is a large gap between the objectives of politicians and those of civil servants and the citizens that the policy is supposed to serve. This is the case in a country like Kenya, where politicians have no ideological leaning but change policy positions not on account of ideology but out of political expediency.

\section{Nurturing Emerging Tech Entrepreneurs}

In their book Start-up Nation, Senor and Singer (2009) demonstrated the power of innovation and entrepreneurship to propel an economy to unimaginable growth levels. They detailed how Israel nurtured technology start-ups by investing in research and development to become one of the major global players in technology, even rivaling Silicon Valley. In 2008, Israel, a country of 7.1 million people with no natural resources, attracted "close to $\$ 2$ billion in venture capital, as much as flowed to the U.K.'s 61 million citizens or the 145 million people living in Germany and France combined" (Senor and Singer 2009). The success was largely due to the "government's macroeconomic policies that played an important role in speeding up the country's growth, reversing it, and then unleashing it in ways that even the government never expected" (Senor and Singer 2009).

However, start-ups do not just grow; they are nurtured. Technology entrepreneurs get advice from a variety of sources, including directors, 
advisory board members, friends, and informal advisors (Choi and Stark 2005). These advice networks serve as important sources of information about business, technical, and social issues for the entrepreneurial community.

Applied to policymaking in the Kenyan context, this means that a combination of an enabling policy environment, investments in research and development, and good advisory networks are necessary for nurturing a successful technology entrepreneurship start-up program. And in fact, sustained government interventions contributed to the success of several start-up support systems in Kenya, such as iHub, iLab, M-Lab, and $88 \mathrm{mph}$.

Two of the policy interventions discussed below were instrumental in putting Kenya on the global ICT map.

\section{Policymaking in the Kenyan Context}

Public policymaking in Kenya in the decade under review was made more complex by the fact that it was happening in an environment of emergent technologies - and of policymakers with limited experience in the subject matter and even less of the skills necessary to build bold, innovative policies.

As in other countries, most public policies are the result of a change in political leadership. In Kenya, the ministries or departments develop a policy statement in line with the vision and political agenda of the incoming administration and pass it on to the cabinet-composed of the president and the cabinet secretaries. Once the cabinet has approved the policy statement, it is then shared with stakeholders for comments to reflect the demands of the Kenya Constitution (Government of Kenya 2010), which demands that policymaking be consultative, participatory, collaborative, and transparent.

This constitutional requirement notwithstanding, achieving meaningful consultation is a core challenge of policymaking in Kenya. This is because leaders often assume that the public participates meaningfully and agrees with the proposed agenda when, in 
reality, the opposite is true. In many cases, there is lack of incentive for the public to meaningfully contribute to the policies that affect them. Additionally, in most public consultation hearings, Kenyan civil society actors highjack hearings and turn them into avenues for political debate on other issues.

Once the consultative period has ended, public views are incorporated into the policy document, which is then sent back to the cabinet for the final approval. If no existing legislation exists on which the policy can be underpinned, the policy is accompanied by a new draft bill.

If a policy goes through these stages successfully, it is then forwarded to the Attorney General's office to ensure it does not conflict with other policies or laws. If it requires legislation, it is then forwarded to Parliament for deliberations as a bill before it become an Act (law) after receiving presidential assent. Policies that do not require any legislation (i.e., where a legal framework exists but there are no regulations) are published in the Kenya Gazette. After publication, implementation of the policy starts.

The time it takes for any policy document to go through all these stages can range anywhere from six months to ten years, mostly depending on the commitment and influence of the sponsoring ministry and of the cabinet. When a policy contains contentious issues that politicians do not want to deal with, it might even take longer. For example, an attempt to develop a Freedom of Information Law, which seeks to ensure that every citizen has a right to information, encountered resistance. This bill has taken more than ten years and has yet to be passed by Parliament simply because politicians think that citizens will gain access to their sensitive data. With this kind of highly politicized policymaking process, it is no wonder that development in most developing countries becomes paralyzed.

Fortunately for us, before the the promulgation of the 2010 constitution, the president had powers to bypass the cabinet and have a policy in place within a week. The minister and I, working closely with the president, exploited this opportunity in executing our ICT projects in record time. However, presidential discretion was a double-edged sword. 
Using the presidential powers, we were able to push through other policies that, although lying outside our purview, were necessary to the success of our sector. The five policy objectives we identified-development of and access to affordable infrastructure, content and innovation, capacity building, public-private partnership, and the creation of employment opportunities — each required its own several sub-policies or its own policy statement. Public-private partnership, for example, was a broader policy that fell within the purview of the Ministry of Finance but was an important policy for my department's goals in ICT development.

\section{Problem Statement}

Innovation precedes policy in emerging areas such as ICTs. This, however, should not happen if significant resources are committed to research and development. Until 2007, Kenya was among 22 Eastern Africa countries grappling with the challenge of linking the region to the rest of the world through undersea fiber optic cables. The challenge centered on whether it was commercially viable to lay such cables and if the governments required development assistance to build the infrastructure. At the time, no relevant policy existed, and so, naturally, focus turned to the legal guidelines that were required to see the project through to completion.

A steering committee comprising mostly nontechnical government teams from each participating country wanted a policy framework spelling out operations of the proposed project before infrastructure development began. Embedded in some of the engagements were government interests, all of which had engaged experts to help them in the policy negotiations. This was in contrast with the team I led, which took the view that, because we had the political will, all was needed was the creation of a general policy statement that could be modified and updated as construction went on. In my view, it was premature to formulate a comprehensive policy statement in a technical area in which many of the participants had limited subject matter expertise. It would be more effective to develop a general policy to help guide those involved gain more experience and exposure to the technologies being proposed. 


\section{Was Existing Knowledge Sufficient to Address Future Demands for Policy Guidelines?}

The policymaking process under review was happening in the context of rapid dynamic technological advances. The Kibaki administration aimed at minimizing the risk of investing in an area whose contribution to economic development was unknown.

Three subquestions therefore guided our research on the topic: (1) How could new ideas be accepted in the absence of a comprehensive policy? (2) Could an alternative and more dynamic policy environment give us the desired results? (3) Without a comprehensive policy document, how could investors be convinced that the management of the infrastructure would be fair?

What follows is a policymaker's reflection on the policy process that changed Kenya's ICT landscape.

Three cases (projects) that required constant policy revision will be discussed using Dror's general systems theory framework (1969) and Edelenbos and Klijn's (2005) interactive decision-making theory to help explain the rationale of the policy interventions.

The cases illustrate the difficulty of creating a dynamic policy environment owing to personal vested interests as well as scant technological knowledge by some government officials.

\section{General Systems Theory: A Recapitulation}

Dror is an acknowledged contributor to policy literature. In The Capacity to Govern (2001), one of his more remarkable works, he argued that a distrust of government has caused a brain drain from elected political positions. Other stakeholders in the political process-industry, civil society, and nongovernmental organizations-however important, he argued, cannot compensate for government's role in defining policy, which it is democratically empowered to do. Dror argued that radical improvements in governance were urgently needed but noted the scarcity of salient policy proposals to achieve this. 
The Capacity to Govern diagnosed contemporary governments as obsolete and proposed changes in values, structures, staffing, public understanding, and political culture to equip governance for the radically novel challenges of the twenty-first century - and, as such, provided an appropriate lens through which to understand ICT policy development in Kenya. The framework of Dror's systems analysis involved three main elements:

1. Looking broadly at problems and alternatives, taking into account many of the relevant variables and of the probable results - in other words, taking a "systems" view;

2. Searching for an optimal, or at least clearly preferable, solution among the available alternatives, without being limited to incremental changes; and

3. Rationally identifying the preferable alternative (or alternatives) through comparison of expected results.

However, in my experience, policy rarely followed such a linear path. The political agenda of leaders is obfuscated by vague and conflicting statements and undefined national goals, and the policymaker has to abstract the real political intentions from such statements, translate them into detailed and actionable targets, and attach appropriate policy interventions to them.

Policymakers frequently delegate policymaking to technical staff, a fact that can widen the gap between intent and actual policy. Standing alone, the general systems approach does not always yield the desired results. There is a need to supplement systems theory with one that describes the consultative nature of policymaking - that is, interactive decisionmaking theory.

\section{Interactive Decision-Making Theory}

Edelenbos and Klijn (2005) argued that proposed solutions are often not inventive enough for policymakers to create effective and actionable policy and that there is a large gap between the objectives of politicians and those of civil servants and the citizens they were elected to serve. 
According to Pröpper and Steenbeek (1998), it is imperative to close the gap between government and its citizens, increase commitment to handling challenges, and create support for an interactive and consultative decision-making process. This involves understanding that the basis of the state-society relationship is that citizens and their leaders have the responsibility and commitment to realize goals are in the public's best interest. Klijn and Koppenjan (2000) suggested that the closure of the gap between the government and its citizens typically has a positive impact on the legitimacy (in terms of support and acceptance) of the government.

Research camed out by Van der Veen (1999) in the Netherlands on local governments that have experimented with interactive and consultative decision-making found that the influence of citizens and interest groups on public policymaking was enhanced. The main motivations for involving stakeholders in interactive decision-making are to diminish the veto power of various societal actors by involving them from the start, thereby improving the quality of decision-making by using the information and solutions of the various actors as well as to bridge the perceived growing cleavage between citizens and elected politicians.

These two theories are useful in looking at, and explaining, the level of feedback loops and interactivity that enabled a dynamic policy development process in Kenya, without which much of the success we have seen in the ICT sector would never have happened. To illustrate the policymaking dynamism already alluded to in the foregoing discussion, three cases are discussed below. Two were successfully implemented, and one failed.

\section{The East Africa Marine Systems (Teams)}

When I joined the Ministry of Information and Communications, there was an initiative to provide high-speed connectivity and lower the cost of accessing the Internet by linking East Africa to the rest of the world through a fiber optic cable. More significantly, the cable was expected to bring closer the dream of having universal broadband connectivity.

For six years, the 22-country project had remained at the planning stage. The amount of money countries had spent in meetings almost 
surpassed the actual cost of building the infrastructure. Clearly, some of the countries were resistant to the project.

Ultimately, after numerous discussions, it became clear that forging ahead with the project successfully was going to require a unilateral approach. Our Ministry decided to abandon the regional initiative in favour of a Kenyan-led project - a difficult decision to make in light of the politics (local and regional) as well as the vested interests.

The long process from multilateralism to unilateralism started with convincing of our minister, Mutahi Kagwe, of the need to abandon the common initiative, which was characterized by political machinations. Next, the minister convinced the then-Minister for Finance, Amos Kimunya. Three of us met with the president and convinced him that the decision we had taken was good for the country. Within three days, we developed a temporary policy document and a cabinet memorandum (the first step in any policymaking in Kenya).

We then sought the direct intervention of President Kibaki, who, having concurred with our assessment, agreed to search quickly for a partnership to develop an alternative to the regional initiative.

We faced a policy challenge. In 2008, Kenya did not have a policy to govern public-private partnerships. Yet, such a policy was necessary to convince stakeholders that Kenya would lead the project. To save time, we proceeded to get Etisalat Telecommunications Corporation in the United Arab Emirates as a junior partner (15\%). Once we had secured this initial deal, we came back and mobilized local operators to invest in the remaining $85 \%$ of the project. I was sure to modify the original cabinet memo to reflect the partnerships.

Once more we approached the president, and his intervention enabled us to obtain financial allocation from the government for the initial investments in the TEAMS project. To fast-track the project through the rigid procurement procedures, I had incorporated a provision in the cabinet memo allowing for the creation of a steering committee.

This committee included Esther Koimett, the investment secretary who in Kenya is responsible for overseeing government investments and public enterprise, John Waweru (representing the Communication Commission of Kenya [CCK], the telecommunications regulator), and Robert Hunja (director-general of the Public Procurement Oversight 
Authority, the entity that oversees public procurement in Kenya). The committee also included Samuel Kirui (the then-CEO of Telkom Kenya).

With this team mobilized, we quickly developed a memorandum of understanding with Etisalat of United Arab Emirates and sought price quotations to survey the cable route from the two principal global operators, Tyco and Alcatel. Tyco won the USD3 million and immediately started work. Tyco's timely implementation of the project won the confidence of the local operators that we wanted to partner with.

Ordinarily, tenders of such magnitude are published internationally for a period of 28 days, and the whole procurement process can take up to six months. It took us one month. Director General Hunja, seconded by the World Bank to the Kenya government, quickly understood the project's benefits and appreciated our high level of commitment. A forward-looking Hunja guided the committee in navigating through the 2005 Procurement Act, Kenya's newly launched procurement law.

There were still policy challenges around this public-private partnership project. To calm investors, I created a board consisting of all of those who had expressed interest in being part of the process-largely local telecommunication companies. And with that TEAMS was born. The TEAMS board created an escrow account to use as a vehicle to mobilize the resources required to build the cable. This enabled us to proceed with the tender to construct the cable. Technically, TEAMS was a government outfit that was subject to procurement rules, but the project was new, and some of the procurement processes of building undersea cables had not been anticipated in our laws. This forced us to rely on the United Arab Emirates' procurement processes as per agreement with Etisalat and eventually with Alcatel, which became the contractor.

\section{Headwinds}

The process moved at a remarkable speed, but not without challenges. By the time the local media were beginning to question the logic of abandoning a regional initiative, we were close to starting the actual construction. We encountered hostile media. Around that time, the government had introduced a Media Bill requiring self-regulation of the media industry. 
Because the media perceived it as an attempt by the state to control media, we concluded that this was main reason for the media hostility.

In addition, the Eastern Africa Submarine Cable System, the regional cable we had abandoned, and another private initiative put pressure on us to abandon the initiative. The media accused us of flouting procurement rules. This prompted the Ethics and Anti-Corruption Commission, the African Center for Open Governance (Africog), the Efficiency Monitoring Unit, the auditor general's office, and a host of other civil society investigative agencies to start probing the project.

Adding to the challenges was the post-election violence in Kenya after the disputed presidential elections of 2007. From my 11 th-floor office at Teleposta Towers, I watched anti-riot police patrol Nairobi's streets. The project contractor, Alcatel, wanted legal and financial guarantees in order to start the work. And Parliament, which approves such guarantees, was not in session.

I consulted Joseph Kinyua, my counterpart at the Treasury Department and an optimist like me who shared the dream of bringing ICT to Kenya. He suggested that I approach the CCK, the then industry regulator, or Kenya's biggest telcom, Safaricom. Both these entities had the financial capability to provide a guarantee.

Michael Joseph, Safaricom's CEO at the time, was sympathetic to my request but said it would require Safaricom board approval. I concluded that selling the idea to the Safaricom board would be a tall order and decided to pursue other means. I approached John Waweru, the directorgeneral of CCK. Here too we needed board approval. I pushed the agenda through, because I was a board member at CCK. That evening, I lobbied the board members one by one, and by the time the board met, I had sufficient support, and they approved the provision of the guarantee. This did not go down well with Patrick Musimba (now the member of Parliament for Kibwezi) who, shortly thereafter, resigned from his board position. Permanent Secretary Kinyua then gave confirmation to CCK's bankers about the deal, Citibank, which needed confirmation from the Treasury before it could give the guarantee.

We secured the guarantee a few days before the March 2008 signing of the National Peace Accord, which brought peace to Kenya, and within days Alcatel moved ships to the United Arab Emirates to begin laying cable. 
At the time, many political changes were occurring. My very supportive minister, Mutahi Kagwe, had lost the local election. Unlike today, under Kenya's old constitution this meant that he could not be appointed as a cabinet minister. President Kibaki appointed Samuel Poghisio as the new minister and retained me in the same position as permanent secretary. The new minister, Samuel Poghisio, was a former university teacher like me, and we developed a good working relationship.

\section{Probes}

Criticism against the project was unrelenting. More than seven different investigative agencies demanded information. The majority of the investigators had little knowledge of the undersea fiber optic cable. One investigator demanded, "Do you really think the entire country is foolish enough to believe that a 5000 kilometer wire can be laid under the sea?" Africog had hired expert investigators whose sound and objective analysis was invaluable in helping us explain the project. I convened a press conference and stated that I would take full responsibility for any impropriety in the project. This reassured the public, but it is noteworthy that we spent close to USD1 million dollars making copies of everything, including thousands of A2-size marine survey documents for transmission to the phalanx of investigators.

Just as we were beginning to see progress, the Privatization Commission was created to provide a legal framework for public-private partnerships and other privatization projects. TEAMS had been a shell company registered as a government entity, which came with a number of repercussions. In order to meet the tight deadlines of the commission, we had to allocate shares to investors. This meant hiring an accounting firm to value the "assets," a highly bureaucratic task. The investors grew agitated as I argued that the law could not be applied retrospectively while maintaining that it was useless to bring in an accounting firm when we had been making payments through a jointly owned escrow account, of which all members of the consortia were signatories. Fortunately, some commissioners began to understand my case. The chairman of the Commission was a professor of economics and a colleague from the university who 
explained the intricacies of the matter to his commissioners, and they eventually approved the partnership.

The benefits of the cable were felt from the start in 2009. Eric Hersman, for example, an American-Kenyan tech enthusiast, asked me to provide at least 40 megabits for an open space he was developing to enable young people to access broadband for free. I embarked on establishing subsidized connectivity to the space, which was later known as the iHub. I gave directives that Telkom Kenya, one of the operators that had been acquired by Orange, a French conglomerate, was to provide the needed broadband. As I waited to hear the good news that iHub had been connected, Telkom sent me an invoice for USD200,000_-money my ministry did not have. Clearly, few people had understood the concept of subsidized broadband to stimulate innovation.

Hersman later secured development assistance and raised capital to deliver broadband to iHub, which later became a hotbed of innovation. Kenya's journey as a center for tech start-ups had begun.

The experience of developing TEAMS was a turning point in the development of the current public-private partnership policies and legal frameworks that are now used in implementing ICT policies in Kenya. Its dynamic policy development process enabled the project to be realized in a timely manner. Other aspects that led to the success of the project were having the courage to take entrepreneurial risks and, even more important, collaborating with industry through an online policy dialogue platform known as the Kenya ICT Action Network KICTANet, which has a global membership that shares best practices and seeks to have them implemented locally.

\section{M-PESA: A First-of-Its-Kind Money Transfer Tool}

As we pursued our infrastructure development goals, another innovation with profound implications for monetary transactions emerged: M-PESA. Like TEAMS, it called for policy that did not exist and that needed to be created. In 2006, Michael Joseph, the CEO of Safaricom, a leading telecommunications provider in Kenya (partly governmentowned) sought my ministry's approval for this new application, to be used to transfer money via mobile phone. 
The application required approval from the Central Bank of Kenya, which Joseph found difficult to obtain without my ministry's support. After seeing a demonstration, I concluded that M-PESA was easier to use than Posta Pay, a government-owned money transfer app used by the Postal Corporation of Kenya and so I promised to support the project.

I contacted the Central Bank in order to get support, allowing Safaricom to test mobile money transfer in Kenya. The then acting governor of the Central Bank, Jacinta Mwatela, was extremely cautious and understandably so. In the 1990s, Kenya had lost about USD600 million through false claims to the government's export-compensation scheme. The Central Bank had paid out these monies to a company called Goldenberg International Limited, ostensibly as an incentive to boost exports of gold. Investigators later found that no gold was exported or that it was gold smuggled in from Congo.

Because of her negative experience with Goldenberg, Mwatela declined to support M-PESA and advised me to do the same. She doubted the novel project and eventually asked me to put my request in writing. In response to my letter, Mwatela sent four members of her staff to meet with Safaricom executives and me. They were clearly impressed by the presentation, although they made no promises. The bank directed that our ministry, which was responsible for both Posta Pay and Safaricom, take the responsibility for the oversight role. I accepted.

At the same time, I decided to seek the bank's formal approval through the Treasury. I wrote a letter that I hand-delivered to Permanent Secretary Kinyua, who by virtue of his position also sat on the bank board. At the time, there existed neither a policy nor a legal framework for the M-PESA kind of technology, which informed my decision to hand-deliver the letter. Had I simply mailed the letter, he would have marked it for a senior official to look into existing policy—and naturally, because the policy was nonexistent, my request would have been rejected.

I explained to the permanent secretary that Kenyans needed a quick and efficient way of sending money and that the existing Posta Pay transfer could not possibly deliver the efficiencies implicit in the M-PESA model. As an economist, the permanent secretary wondered whether M-PESA could affect the money supply and cause disruptions. However, the plan was that Safaricom would work with the banks to execute the 
project so it would not affect the money supply. The permanent secretary agreed to help.

In the meantime, I asked my policy team, led by Dr. James Kulubi, to draft an electronic transactions bill and a policy document. In addition, I briefed Ambassador Francis Muthaura, Secretary to the Cabinet and the Head of Public Service, about the new concept and its enormous positive implications for the economy.

Ambassador Muthaura encouraged us senior servants to take measured risk and inject new ideas into the public service. M-PESA was a gamble, and if it failed my career was on the line. I lobbied parliamentarians, especially the ICT-energy subcommittee that oversaw the operations of our ministry. Much of my lobbying consisted of "market education" to try to help ensure that the members understood the new product and its potential to revolutionize the money transfer industry in Kenya.

At the Central Bank, a new governor, Prof. Ndung'u Njuguna, was appointed. He was an open-minded academic who soon after his appointment declared that the M-PESA concept would not pose any danger to the Kenyan economy.

With that, Safaricom's Michael Joseph proceeded to implement M-PESA in 2007, establishing Kenya as a world leader in mobile money transfer technology.

Clearly, M-PESA is a classic case in which innovation preceded policy. In such cases, policymakers take the risk and, through systemwide consultations, push for supportive policies.

\section{Posta Land Development: A Failed Policy for the Public Good}

In 2009, after paying a courtesy call to Kenya's President Mwai Kibaki, the presidents of two giant global corporations said they wanted to invest in a social enterprise in Nairobi that would create 10,000 businessprocess-outsourcing jobs. In return, Kenya was to provide at least five acres of land where the two communications giants would build their enterprise. President Kibaki requested that I find the land and report back to him. 
Although our policy to develop a technology city at Konza was on track, this was an urgent opportunity. After a futile search through the Ministry of Lands, we identified land owned by the Postal Corporation of Kenya at an upmarket area near the well-known Yaya Shopping Center, 15 minutes from Nairobi City Center. The government assessor valued the land at Ksh 460 million (USD4.6 million).

I directed our legal teams to find out how we could legally transfer it to our new investors. They quickly came back with the laws on public land disposal, which had very detailed procedures, including approval by the board, the minister in charge, and finally the finance minister, who is the custodian of all government property. The legal team went through these steps very carefully.

Despite following the law to the letter, we encountered resistance. The Ethics and Anti-Corruption Commission suspected that the land was being acquired unlawfully by a large multinational corporation. This triggered a letter from the Commission warning that if I proceeded with the process, I would be charged in court. I called the Commission's Executive Director Prof. P.L.O. Lumumba and carefully explained the matter.

A few days later, however, Prof. Lumumba gave a public lecture in which he censured permanent secretaries for being complicit in corruption. Specifically, he insisted that the procurement of land must be consistent with the procurement law. In this case, the eloquent Prof. Lumumba was wrong, because the procurement law had no provision for land disposal.

Prof. Lumumba and the Commission as well as the Postal Corporation officials failed to appreciate that, given the rapid decline of postal services, we needed innovative technologies such as the business process outsourcing for job creation.

The challenge was that the public procurement and disposal law did not adequately address the sale of land for such developments. The disposal that was allowed by law was for minor equipment. The law did not bar disposal of land but required a much more elaborate process to be executed for the sale of public land.

Land values in Kenya have greatly appreciated, and land cannot be disposed of without valuation. I sent the details of the process we had followed to the Commission. Once again, it insisted that we follow the 
procurement law. By this time, one of the giant corporations had gotten wind of the fact that we were subjecting the matter to the procurement law and offered to pay the valuation price. Posta immediately tried to scuttle this new development by failing to effect board decisions. The Commission wrote again, insisting that the land should be sold to the highest bidder. The risk from our perspective was that the highest bidder might turn out not to be the companies that caused us to embark on the project in the first place.

I briefed Ambassador Muthaura, who issued a directive that the land be sold at the valuation price. The Commission ignored the directive and wrote to me saying it would hold me personally responsible. To complicate matters, the management of Posta refused to sign off on the land. We contemplated a disciplinary action against management. However, if such a recourse got into the media, it would be costly to the corporate image of the two global giants that just wanted to create job opportunities through ICT development.

Later, I discovered that some employees in Posta were enjoying a monthly income from leasing the land in question to informal motor vehicle dealers. Out of self-interest, they may had looped in some junior Commission officials in destroying a deal with a huge potential to create much-needed jobs in Kenya and thwarted an important step toward advancing ICT innovation.

The Posta case is significant in policymaking, because it illustrates how policy of any kind cannot work where personal interests obscure decision-making. It also shows that, although the upper echelons of government might formulate a policy, middle-level managers can ultimately sabotage the policy out of personal interest. Both the general systems and interactive decision-making theories work on the assumption that there is transparency among all players. The reality is that often there is none.

\section{Implications for Policy}

The TEAMS and M-PESA cases related here are two projects that sparked ICT innovation in Kenya. In hindsight, the risks were worth taking. They illustrate how dynamism in policy development can lead to greater 
development by creating an environment where entrepreneurship and innovation can flourish.

The success of the TEAMS project was largely due to the fact that decisions were made interactively and transparently, with the involvement of many stakeholders. We facilitated the timely completion of the project by giving information when it was needed, and the investors deliberated on issues internally before making decisions openly.

Through the 4000-member-strong industry portal KICTAnet, I responded directly to the public's questions, enabling us to enrich the content and advance it toward the usage policy we aimed to create. This process of interactive and consultative decision-making, as described by Edelenbos and Klijn (2005), lent the much-needed support to the project, enabling its completion in record time.

M-PESA became the enabler of e-commerce in Kenya, which had hitherto stagnated because of low credit-card penetration. Virtually every month following the introduction of M-PESA, I taught online start-ups about M-PESA's application program interface, which specifies how software components should interact to create smooth payments between two different firms. Many more developers in Kenya were inspired by what M-PESA could achieve and tried to emulate it. A few have succeeded. Nevertheless, the motivation had been established, leading application developers to bring their expertise to other sectors, mainly agriculture, health, and education, where they have helped create massive efficiency improvements.

For this project, the theoretical approach that fit its execution was Dror's general systems theory, because those involved in pushing the policy through attempted a structured, rational way of enabling a new innovation to go to market. There was a degree of interactivity, too, especially when convincing certain players of the merits of a particular approach or perspective. My intentions were to get both the Treasury and the Central Bank to look at the problem in a broader sense. Although there were not many options, they could at least agree to a pilot program. My desire was to get to rational identification of the preferable alternative-in order to allow Safaricom to proceed. And in the end, this is what actually occurred.

The failed land acquisition was a major setback. Business process outsourcing was the main reason we sought to build ICT infrastructure in 
the first place. The project would have sparked off a new service industry. However, it was derailed by the self-interests of a handful of public servants. They were veterans of the system and were able to ignite squabbles between the two public service departments and continue with their "business as usual."

However, all of this offers a great lesson, in that when there is resistance to change and innovation, one must be flexible and react accordingly. One mistake we made in executing a presidential policy was the fact that we dealt with those at the strategic level, ignoring and hurting the feelings of the mid-level managers who usually execute policy.

Self-interest and other ulterior motives are often responsible for creating paralysis in policy formulation and implementation. In retrospect, there are many things that we ignored and that led, as a result, to our policy failure. We should never have assumed there would be no resistance from Postal Corporation. Had we applied interactive decisionmaking theory to the Postal case as in the other cases, we might have succeeded. Without making any assumptions, we should have involved many more stakeholders, who would have prevailed on the officers to let go of their personal motives. And we should at least have involved not just people at the strategy levels but the senior officers and other field staff.

\section{Conclusion}

This chapter has revealed that there is benefit in a continuous review of policy to facilitate the emergence, commercialization, and monetization of new technologies. The chapter focused on three case studies in Kenya: the TEAMs project, the development of M-PESA, and the Posta land development project.

From the case studies, it is clear that in any policy implementation, a mechanism for involving as many stakeholders as possible is critical. Such mechanisms might include leveraging known theoretical foundations, such as interactive decision-making, which seeks to create a collaborative setting where stakeholders deliberate on a policy to reduce the gap between political proposals and what the citizens expect. 
Other mechanisms involve general systems theory in order to arrive at a rational decision after taking all of the issues into consideration. Our two successful projects were successful because they applied strategies based on these theoretical foundations. Our failure in the third case study was caused largely by the wrong assumption that a direct policy pronouncement from the head of state would result in automatic implementation. The opposite was true - a lesson that any policy needs some process to succeed.

If we fuse the analytical frameworks of general systems theory and interactive decision-making theory, we can use them to understand ICTrelated policymaking in the Kenyan context. Using this approach, it becomes evident that a combination of the right policy environment, strong political will, smart investments in research and development, and good advisory networks led to effective policymaking and laid the foundation for Kenya's ICT boom.

For all its worth as an examination of case studies in policymaking, this chapter is still a personal narrative whose aim was provide the perspectives of three distinct cases of policy development in the context of emergent technologies in a developmental and democratizing setting. It is therefore not a generalizable view of policymaking. The insights from the chapter, grounded in theoretical analysis, however, might serve as a starting point for other policy practitioners seeking to understand the birth of ICT in Kenya.

\section{References}

Choi, D. Y., \& Stark, M. (2005). Who adds value to ventures? Understanding the roles and relative contributions of key advisors in high-technology startups. The Journal of Entrepreneurial Finance, 10(3), 75-87.

Dror, Y. (1969). Systems analysis for development of administration: Some problems and requisites. Santa Monica: The Rand Corporation. Presented at the national conference on public administration, Miami, Florida, May 19-21, 1969.

Dror, Y. (1983). Public policy-making re-examined. New Brunswick: Transaction Publishers. 
Edelenbos, J., \& Klijn, E. (2005). Managing stakeholder involvement in decision making: A comparative analysis of six interactive processes in the Netherlands. Journal of Public Administration Research and Theory, 1-30 (Advance Access published July 6).

Geurts, T. (2014). Public policy making: The 21st century perspective. Be Informed. Lulu.com.

Government of Kenya (2006). National Information and Communications (ICT) Policy. Nairobi: Government of Kenya.

Government of Kenya (2010). Constitution of Kenya. Nairobi: Government of Kenya.

Klijn, E. H., \& Koppenjan, J. F. M. (2000). Politicians and interactive decisionmaking: Institutional spoilsport or playmakers. Public Administration, 78(2), 365-387.

Pröpper, I. M. A. M., \& Steenbeek, D. A. (1998). Interactieve beleidsvorming: Typeringen, ervaringen en dilemma's'. In: Bestuurskunde, jrg. 7, nr. 7, 1998. Translation by van der Veen available at: http://cfpm.org/firma/Documents/ Interactdecmaking.htm. Accessed 22 Feb 2016.

Senor, D., \& Singer, S. (2009). Start-up nation: The story of Israel's economic miracle. New York: Twelve Publishers.

van der Veen, A. (1999). Interactive decision-making: A review report to the FIRMA project Enschede, the Netherlands: University of Twente. http:// cfpm.org/firma/Documents/Interactdecmaking.htm. Accessed 22 Feb 2016. 


\title{
Conversation \#11
}

\section{Why Policy Matters for Entrepreneurs}

\author{
Ory Okolloh of Omidyar Network Africa
}

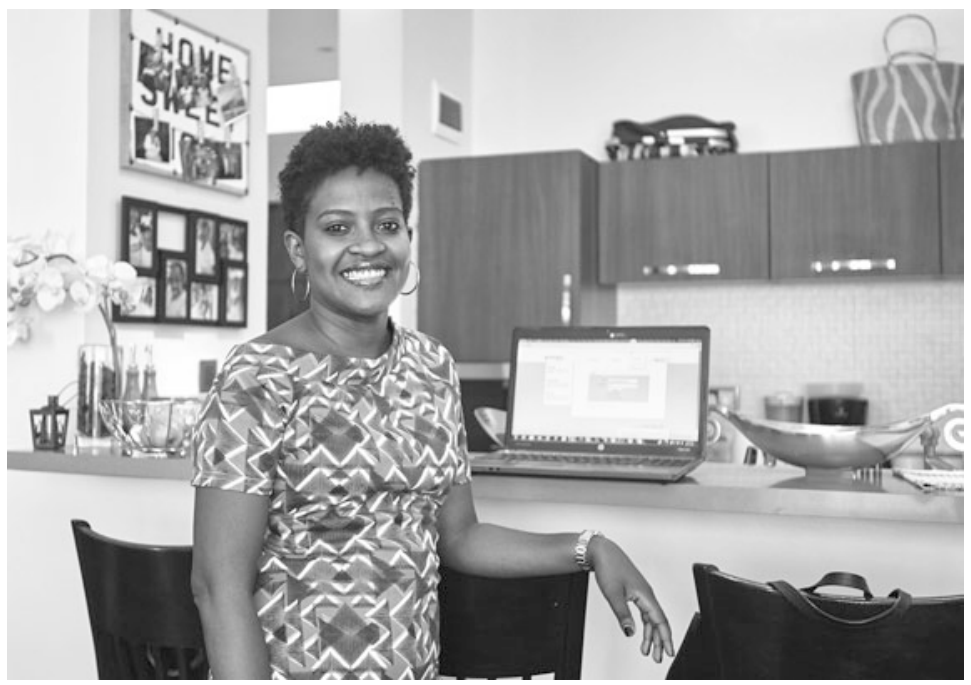

Ory Okolloh is a well-known commentator on technology trends and governance in Africa. She has worked with organizations like Omidyar Network, Google Africa and the World Bank. She is also a co-founder of Ushahidi and Mzalendo. In 2014, she was recognized as one of Time Magazine's 100 most influential people in the world. 
Ory, you have been involved in Mzalendo and Ushahidi, you have worked for Google, and you are now in the investment space with Omidyar. You are also an active blogger and trained lawyer. How do all these different roles fit together?

I consider myself an active citizen of the world, and if something bothers me enough, then I will do something about it. I got into technology because it allows me to reach out to a number of people at once. Primarily, my efforts are directed less at solving issues but rather aimed at creating a platform that can enable citizens to solve the problems they deem relevant. Mzalendo, for example, was created to give citizens access to vital information on relevant government issues. The basic idea behind Mzalendo was to create awareness about the role and work of Members of Parliament in Kenya and increase the accessibility of such information. For Ushahidi we developed a similar idea, with a different spin to it. At Ushahidi we built a platform that allowed people to crowd-source information directly without intermediaries. My work at Google continued in a similar vein. Few things scale better than Google initiatives and at Omidyar, I am concerned with identifying the tools that entrepreneurs and innovators in our region require to succeed and scale beyond national borders. In sum, I am motivated by how I can put my skills to use most effectively - that is, providing a platform so that problems become visible and get solved.

\section{How would you describe your work at Omidyar?}

My task is to bring an African perspective into the investment opportunities. We need more investments into ventures that make sense for the region and its entrepreneurs. This simply requires a thorough understanding of both the region and the investment opportunities. For example, on the entrepreneur side, we need to demystify the art of pitching and marketing. By the same token, we need to make sure as investors that we are staying close to the trends and to how African economies are evolving. All in all, I believe that by being more connected to the region and its entrepreneurs you will identify the hidden jewels that can have an immense impact.

\section{Why are many entrepreneurs likely to disengage with the govern-} ment, or "fly under the radar," as it is often called?

Not just in Kenya but in the whole of Sub-Saharan Africa you find very young democracies that suffer from high unemployment rates 
and incapable governments that are failing to provide basic services. As a consequence, the perception that you should not rely on public goods has become the status quo-up to a point where the rule of thumb has become that the less you deal with government the better. We have become very creative and innovative in developing entrepreneurial solutions that work around public goods failures. However, at some point, you will notice that you are stuck, and you will have to engage with public policy. I believe that this idea-not expecting anything from your government-is harmful. Entrepreneurship and government are not two separate issues. They are interdependent right from the start.

There is a reason why industry lobbies in Europe and America are so powerful. Yes, they are entrepreneurs but they also leverage public policy to raise issues that are of concern to them. There is a reason why Obama and any presidential candidate in the general elections in the USA has to engage with the Silicon Valley lobby. All the government chief technology officers at the current White House, for example, have been former employees of big technology companies like Google or Facebook. Engagement with the government, as entrepreneurs, is absolutely common and needed. If this is the norm in the West, then why are we being asked to ignore the government?

Let's take procurement, for example. Why are African governments not procuring more from local technology entrepreneurs if they have the capability? How do we expect the local tech sector to grow if there are no policies in place to support it? Issues like this need to be put on the table and require a solution for the benefit of the region's ICT sector.

\section{Who are the kinds of entrepreneurs that tend to get more involved in channeling information to policymakers?}

We are starting to see more senior entrepreneurs become involved. Engaging the government is hard work and requires persistence. You cannot expect to knock on their door and see the change immediately coming through. Long meetings with policymakers where you move one step backward to go one forward are exhausting, especially when you know 
that you could be using this time for your business and get way more done. However, when the new solution that you crafted with policymakers becomes national and permanent, meaning a law, then you have achieved something for everyone else as well. Entrepreneurs should see this as a different kind of hack.

\section{Let us say entrepreneurship also has a flavor of being an activist for society. Then what should the role of the government be?}

The role of the government should be to create an opportunity for entrepreneurs to thrive. That is it! I am not pushing toward the other extreme, in which government will have to do everything. I am advocating for an enabling environment.

If we step back, reflect, and realize that the Kenyan population is in general quite entrepreneurial then we can start shifting some of the responsibility to them rather than shifting it even further away from them. Governments and policymakers do not need to do everything by themselves. What if we created an environment where we can act out our entrepreneurial nature for society as a whole? If you ask someone now for a short list of items that need to change, they will tell you that they do not want to deal with the Nairobi City Council every two days as they pass by the shop or that they need a streamlined business registration process-one unified license-or that access to financing needs to be addressed. An interest rate of $25 \%$ is not really very conducive to doing business.

However, when we disengage completely, then there is no pressure for people on the other side to do their jobs.

\section{What are some solutions you have observed to get the government involved?}

I am interested in the recent revival of residence associations, which was mostly driven by security concerns that are by now evolving into other issues. I am fascinated by the Kilimani Project Foundation, as an 
example. ${ }^{2}$ It was formed by businesses and residents in the Kilimani area and provided a forum of vital exchange in the community. The idea goes back to a famous book, Bowling Alone: The Collapse and Revival of American Community, which analyzed the decline of in-person social interactions and how this basically undermines democracy. So you have to understand your neighborhood as a community where you have clear responsibilities as residents or business people and, on the other side, figure out who is responsible for doing what in government. For example, if there is a blocked drain on your street, it is more effective for you to complain collectively to the right local government entity than to solo on social media.

All in all, we need to think about ways to keep the government involved, rather than thinking of ways to stay under the radar. If we do not bring forth the issues that matter to those that can change them, then we will end up, if we are unlucky, with solutions that are only a temporary fix-or with no solutions at all.

\section{Thanks you, Ory!}

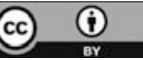

This chapter is distributed under the terms of the Creative Commons Attribution 4.0 International License (http://creativecommons.org/licenses/by/4.0/), which permits use, duplication, adaptation, distribution and reproduction in any medium or format, as long as you give appropriate credit to the original author(s) and the source, provide a link to the Creative Commons license and indicate if changes were made.

The images or other third party material in this chapter are included in the work's Creative Commons license, unless indicated otherwise in the credit line; if such material is not included in the work's Creative Commons license and the respective action is not permitted by statutory regulation, users will need to obtain permission from the license holder to duplicate, adapt or reproduce the material.

\footnotetext{
${ }^{2}$ See http://kilimani.co.ke/
} 